\title{
Pengembangan Lembar Kerja Peserta Didik (LKPD) Berbasis Problem Based Learning (PBL) Pada Materi Laju Reaksi
}

\section{Development of Student Worksheets Based on Problem Based Learning (PBL) on Reaction Rate Material}

\author{
C F Yanti ${ }^{{ }^{*}}$ and Suryelita ${ }^{1}$ \\ ${ }^{1}$ Pendidikan Kimia, Universitas Negeri Padang, \\ Jl. Prof. Dr. Hamka, Air Tawar Barat, Padang Utara, Sumatera Barat, Indonesia 25171 \\ * cinthreefauzanayanti@gmail.com
}

\section{ARTICLE INFO}

Received on:

23 June 2020

Revised till:

29 August 2021

\section{Accepted on:}

31 August 2021

Publisher version published on:

08 September 2021

\begin{abstract}
Reaction rate material is facts, concepts, calculations and practicum. Learning requires teaching materials to help students find their own concepts starting with contextual problems, one of which is PBL-based LKPD, because it can help students understand concepts through problems so that students are required to think more actively. The research aims at producing alternative teaching materials (helping active students in understanding the material) and determining the validity category. The type of research is $R \& D$ with a $4-D$ model, define, design, develop, and disseminate (not done). The study was limited to the validity test with the research instrument, namely the validity questionnaire. The data collection technique was carried out by distributing questionnaires. The research data by five expert validators were analysed using the Cohen kappa formula. Based on the analysis, the resulting $L K P D$ with a very high validity category is 0,83 .
\end{abstract}

\section{KEYWORDS}

4-D Models, LKPD, Problem Based Learning, Reaction Rate, Validity

\section{ABSTRAK}

Materi laju reaksi bersifat fakta, konsep, perhitungan dan praktikum. Pembelajaran membutuhkan bahan ajar untuk membantu peserta didik menemukan konsep sendiri dimulai dengan masalah kontekstual, salah satunya LKPD berbasis PBL, karena dapat membantu peserta didik memahami konsep melalui masalah sehingga peserta didik dituntut agar berpikir lebih aktif. Penelitian bertujuan menghasilkan alternatif bahan ajar (membantu peserta didik aktif dalam memahami materi) dan menentukan kategori validitasnya. Jenis penelitian adalah $\mathrm{R} \& \mathrm{D}$ dengan model $4-\mathrm{D}$, define, design, develop, dan disseminate (tidak dilakukan). Penelitian dibatasi hingga uji validitas dengan instrumen penelitiannya yaitu angket validitas. Teknik pengumpulan data dilakukan melalui penyebaran angket. Data hasil penelitian oleh lima validator ahli dianalisis melalui formula kappa Cohen. Berdasarkan analisis, dihasilkan LKPD dengan kategori kevalidan sangat tinggi yaitu 0,83.

KATA KUNCI

Model 4-D, LKPD, Problem Based Learning, Laju Reaksi, Validitas 


\section{PENDAHULUAN}

Kurikulum 2013 bertujuan untuk menciptakan masyarakat Indonesia yang proaktif, inovatif, kreatif, berilmu, dan juga mandiri ${ }^{[1]}$. Kurikulum saat ini menerapkan pembelajaran menggunakan pendekatan saintifik (scientific approach). Scientific approach mengharapkan peserta didik menghasilkan karya kontekstual, aktif menemukan konsep, mampu memecahkan masalah dan mampu meningkatkan kemampuan critical thinking ${ }^{[2]}$. Hal ini dapat diterapkan dengan model PBL.

Model PBL yaitu model pembelajaran yang dapat mengembangkan kemampuan critical thinking, penyelesaian masalah dan membantu peserta didik aktif membangun kognitif sendiri ${ }^{[2]}$. Model pembelajaran ini mengintegrasikan pengetahuan baru melalui working cooperative in groups untuk mengembangkan keterampilan berpikir lebih aktif, memecahkan masalah, dan mendapatkan pengetahuan/ilmu yang bermanfaat dari materi pelajaran $^{[3]}$. Hal senada disampaikan Gunantara, dkk yang menyatakan PBL merupakan pilihan yang tepat untuk mengembangkan pola pikir kritis dan keterampilan berpikir tinggi lainnya ${ }^{[4]}$. Berhasilnya pelaksanaan pembelajaran dengan integrasi model PBL tergantung pada ketersediaan dan kelengkapan perangkat pembelajaran untuk mendukung kegiatan belajar peserta didik ${ }^{[5]}$. Oleh sebab itu, model pembelajaran PBL dapat diintegrasikan dengan LKPD agar peserta didik dapat menyelidiki, menganalisis, dan mencari pemecahan masalah secara mandiri dan berkelompok dalam menemukan dan memantapkan konsep khususnya materi laju reaksi.

Laju reaksi/reaction rate merupakan bagian dari materi kimia kelas XI SMA/MA. Materi ini mencakup tentang konsep laju reaksi, faktor-faktor laju reaksi, teori tumbukan, orde dan persamaan reaksi serta pengendalian reaksi kimia. Dalam mempelajari materi ini, peserta didik dituntut untuk mampu menghitung dan memahami konsep-konsep yang berhubungan dengan materi serta dapat melakukan eksperimen. Karakteristik materi ini dapat dihadapkan dengan masalah kontekstual, sehingga diperlukan bahan ajar yang dapat membantu peserta didik memecahkan masalah, membangun kognitif sendiri agar peserta didik dapat menemukan dan memantapkan konsep sehingga tujuan pembelajaran tercapai.

Berdasarkan angket, pembelajaran kimia di SMAN 1 Koto XI Tarusan menggunakan kurikulum 2013 revisi 2018. Upaya guru dalam menunjang proses pembelajaran yaitu dengan menggunakan buku teks, LKPD, dan media PowerPoint. Pembelajaran membutuhkan bahan ajar dalam membantu peserta didik untuk menemukan konsep sendiri, salah satunya LKPD terbitan Viva Pakarindo. Materi yang disajikan dalam LKPD ini berisi konsep singkat dan belum mencakup materi secara keseluruhan berdasarkan kompetensi dasar yang ada. Untuk itu, guru perlu menjelaskan materi secara rinci dengan metode ceramah. Materi laju reaksi bersifat faktual, konseptual dan prosedural.
Karakteristik materi ini banyak mengandung masalah kontekstual. Akan tetapi, peserta didik belum mampu menemukan konsep sendiri apabila dihadapkan dengan permasalahan kompleks yang berhubungan dengan materi. Hal ini terlihat dari analisis angket peserta didik, yaitu sebanyak 52\% dari 34 peserta didik belum mampu memahami konsep laju reaksi, $52 \%$ belum mampu memahami orde reaksi dan $49 \%$ belum mampu memahami syarat terjadinya reaksi. Hasil tersebut juga sesuai dengan jawaban lembar wawancara guru, diketahui $52 \%$ peserta didik kurang memahami materi laju reaksi, khususnya konsep dan perhitungan.

Berdasarkan permasalahan di atas dikembangkan LKPD berbasis PBL khususnya pada materi laju reaksi yang disesuaikan dengan tuntutan kurikulum 2013, dengan model pengembangan 4-D. LKPD yang dihasilkan menjadikan masalah sebagai langkah awal, berisi lembar kerja yang menuntun peserta didik menemukan konsep sendiri, merancang dan melakukan percobaan secara mandiri. LKPD dengan model PBL diharapkan dapat membantu peserta didik beraktivitas nyata terhadap objek pelajaran, dapat meningkatkan berpikir kritis, menemukan konsep dan memantapkan konsep yang dimiliki secara mandiri. Peserta didik lebih aktif berkomunikasi dengan teman atau kelompok, dan guru yang berperan sebagai pemandu.

Penelitian sebelumnya terkait pengembangan LKPD berbasis PBL telah dilakukan oleh Fitriani (2016), LKPD yang dikembangkan dapat meningkatkan aktivitas belajar dan pemahaman materi peserta didik ${ }^{[6]}$. Jasperina (2019) menyatakan LKPD berbasis PBL memiliki kategori valid dan dapat digunakan dalam proses pembelajaran. LKPD berbasis PBL pada materi larutan penyangga juga memiliki kategori sangat valid dan praktis ${ }^{[7]}$, Astuti, dkk (2018) menyatakan LKPD berbasis PBL pada materi kesetimbangan kimia memiliki kategori valid, praktis dan layak digunakan ${ }^{[8]}$. Rhaska (2020) juga menyatakan LKPD berbasis PBL pada materi laju reaksi memiliki kategori valid, sehingga dapat digunakan dalam proses pembelajaran ${ }^{[9]}$.

\section{METODE}

Jenis penelitian yaitu $\mathrm{R} \& \mathrm{D}$, menggunakan model pengembangan 4D yaitu define, design, dan develop serta disseminate (tidak dilaksanakan) ${ }^{[10]}$. Tahapan diawali dengan analisis Kompetensi Dasar (KD) dan bahan materi pelajaran berdasarkan silabus kurikulum 2013 revisi 2018 pada tahap define. Tahap define ini memiliki langkah-langkah yaitu: pertama, analisis ujung depan, kedua, analisis peserta didik, ketiga analisis tugas, keempat analisis konsep, dan kelima analisis tujuan pembelajaran. Selanjutnya, tahap perancangan (design), merancang perangkat pembelajaran yang akan dihasilkan. Tahap ini terdiri dari 3 tahapan, yaitu: pemilihan media, pemilihan format, dan melakukan rancangan awal LKPD. Rancangan awal LKPD ini disesuaikan dengan format-format yang sudah ada sebelumnya dan sintaks pembelajaran Problem Based Learning. 
Tahapan selanjutnya adalah tahapan pengembangan (develop), menghasilkan LKPD berbasis PBL pada materi Laju Reaksi yang valid digunakan dalam kegiatan pembelajaran. Penelitian dibatasi sampai tahap validasi. Subjek penelitian yaitu dosen kimia FMIPA UNP dan guru kimia SMAN 1 Koto XI Tarusan. Instrumen pengumpulan data penelitian diambil melalui angket validasi. Data dianalisis dengan kappa Cohen ${ }^{[11]}$.

$$
\text { momen kappa }(k)=\frac{\rho_{0}-\rho_{e}}{1-\rho_{e}} \text {... Persamaan } 1
$$

Dimana, $k$ melambangkan Momen kappa, artinya menunjukkan validitas produk; $\rho_{0}$ ialah Proporsi terlaksana, diperoleh dengan cara skor ahli dibagi skor maksimal; dan $\rho_{e}$ ialah proporsi yang tidak terlaksana skor maksimal dikurangi dengan skor yang diberikan dibagi skor maksimal.

Berdasarkan analisis momen kappa di atas terdapat beberapa aspek penilaian. Aspek penilaian tersebut berkaitan dengan kategori valid atau tidaknya bahan ajar yang dikembangkan, seperti terlihat pada Tabel 1.

Tabel 1. Momen kappa Cohen $(k)^{[11]}$.

\begin{tabular}{c|c} 
Interval & Category \\
\hline $0,81-1,00$ & Very high \\
\hline $0,61-0,80$ & High \\
\hline $0,41-0,60$ & Intermediate \\
\hline $0,21-0,40$ & Low \\
\hline $0,01-0,20$ & Very low \\
\hline 0,00 & Invalid
\end{tabular}

\section{HASIL DAN DISKUSI}

Berdasarkan penelitian yang sudah dilaksanakan, dihasilkan LKPD berbasis PBL pada materi Laju Reaksi dengan model 4D (define, design, develop, dan disseminate). Penelitian dibatasi hingga tahap pengembangan dan tahap disseminate tidak dilaksanakan. Pada tahap develop penelitian dibatasi hingga uji validitas. Uji validitas bertujuan untuk mengetahui kategori kevalidan/keabsahan produk yang dihasilkan.

\subsection{Tahap Define}

Tahap define dilakukan melalui observasi 3 guru kimia dan angket yang diisi oleh 34 peserta didik dari SMAN 1 Koto XI Tarusan. Berdasarkan observasi yang telah dilakukan, diketahui beberapa permasalahan seperti: 1) LKPD yang beredar belum mendukung kurikulum 2013 revisi 2018, 2) LKPD yang digunakan belum melibatkan peserta didik secara aktif menemukan konsep, masih terdapat materi Laju Reaksi yang kurang dipahami oleh peserta didik, khususnya konsep dan perhitungan serta belum tersedianya LKPD laju reaksi berbasis PBL sesuai dengan tuntutan kurikulum 2013.
Tahap define terdiri dari beberapa tahap yaitu:

\subsubsection{Analisis Ujung Depan}

Tahapan ini diawali dengan observasi di SMAN 1 Koto XI Tarusan. Berdasarkan analisis lembar wawancara guru dan peserta didik, diketahui LKPD yang tersedia belum mampu membantu peserta didik dalam menemukan dan memantapkan konsep sendiri. 52\% dari 34 peserta didik belum mampu memahami materi orde reaksi, hanya $48 \%$ peserta didik yang memahami persamaan laju reaksi, dan 51\% mampu memahami syarat terjadinya suatu reaksi. Hal ini dikarenakan, LKPD yang ada belum mencakup materi secara keseluruhan berdasarkan kompetensi dasar yang ada.

\subsubsection{Analisis peserta didik}

Berdasarkan hasil lembar wawancara dan penyebaran angket laju reaksi di SMAN 1 Koto XI Tarusan, didapati peserta didik kesulitan memahami materi laju reaksi, seperti konsep dan perhitungan. Hal ini diketahui melalui analisis jawaban lembar angket peserta didik, diperoleh rata-rata hanya $48 \%$ dari 34 peserta didik yang dapat memahami konsep laju reaksi, orde reaksi dan persamaan laju reaksi.

\subsubsection{Analisis tugas}

Analisis tugas materi laju reaksi disesuaikan dengan penerapan kurikulum 2013 seperti analisis kompetensi inti dan kompetensi dasar. Berdasarkan analisis KI dan KD dalam silabus, diperoleh beberapa Indikator Pencapaian Kompetensi (IPK). IPK untuk materi laju reaksi yaitu: menjelaskan faktor-faktor yang memengaruhi laju reaksi berdasarkan teori tumbukan;menentukankecepatan reaksiberdasarkan contoh yang diberikan; menentukan orde reaksi berdasarkan data hasil percobaan; menentukan tetapan laju reaksi berdasarkan data hasil percobaan, menyajikan hasil penelusuran tahapan mengatur bahan untuk mencegah perubahan fisika dan kimia yang tidak terkendali, menyajikan hasil penelusuran tentang penyimpanan bahan agar mencegah perubahan fisika dan kimia yang tidak terkendali, merancang dan melakukan, serta menyimpulkan, menyajikan hasil percobaan mengenai faktor yang memengaruhi laju reaksi. Selanjutnya disusun tugastugas pada tahap penyelidikan individu/kelompok. Tugas membantu peserta didik dalam menemukan konsep sehingga IPK tercapai.

\subsubsection{Analisis Konsep}

Analisis konsep berisi identifikasi konsep utama materi laju reaksi. Konsep utama ini dapat berupa seperti konsep kecepatan reaksi, tumbukan efektif, tumbukan tidak efektif, konsentrasi, luas permukaan, suhu, katalis, dan orde reaksi.

\subsubsection{Analisis Tujuan Pembelajaran}

Tujuan pembelajaran pada materi laju reaksi menggunakan model pembelajaran PBL adalah menggali informasi, penyelidikan sederhana serta dapat mengolah informasi, diharapkan peserta didik dapat terlibat aktif dalam proses belajar mengajar, mampu menjelaskan faktor-faktor laju reaksi 


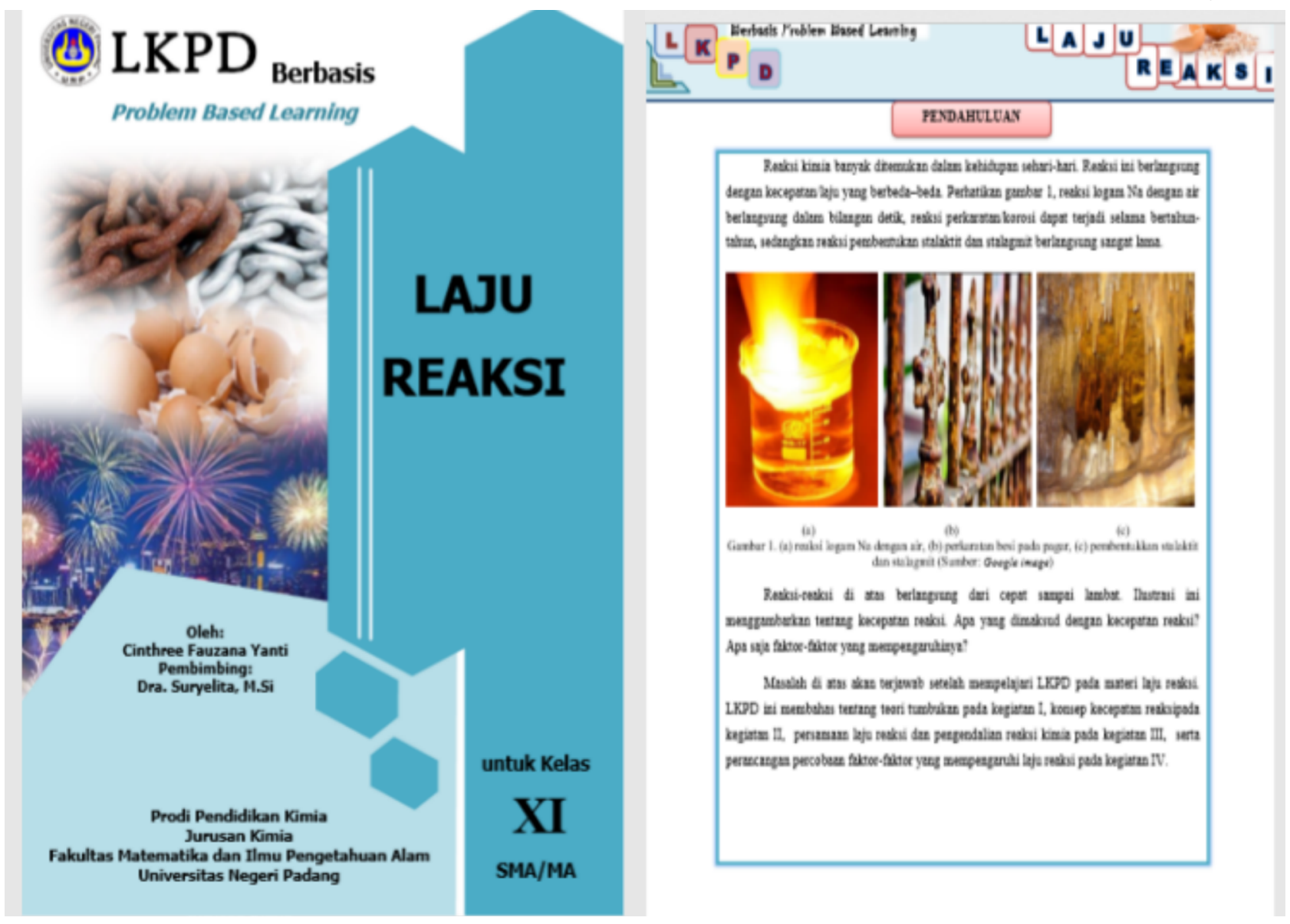

Gambar 1. Tampilan LKPD

menggunakan teori tumbukan, menentukan orde reaksi dan tetapan laju reaksi berdasarkan data hasil percobaan, mampu menyajikan tahapan pengaturan dan penyimpanan bahan kimia, merancang, melakukan dan menyimpulkan, serta menyajikan hasil percobaan faktor-faktor yang memengaruhi laju reaksi dan orde reaksi.

\subsection{Tahap Design}

Design/merancang dilakukan setelah pendefinisian (define). Tahap ini berisi rancangan awal LKPD berbasis PBL pada materi laju reaksi sebagai berikut:

\subsubsection{Judul}

Judul LKPD terdapat pada halaman depan (cover). Halaman ini memuat gambar yang relevan dengan materi laju reaksi seperti gambar contoh laju reaksi dalam kehidupan. Cover juga berisi identitas penulis seperti nama penulis, fakultas dan universitas, identitas pembimbing, dan kolom identitas untuk peserta didik.

\subsubsection{Informasi Pendukung}

Tahap design pada LKPD lainnya memuat informasi pendukung. Hal ini berupa: kata pengantar; daftar isi; profil LKPD; peta konsep; dan daftar pustaka.

\subsubsection{Petunjuk Penggunaan}

Petunjuk penggunaan akan memperjelas peran guru dan peserta didik sesuai dengan sintaks-sintaks PBL dalam pembelajaran. Untuk itu dibuatlah petunjuk penggunaan untuk guru dan peserta didik yang terdapat pada bagian awal bahan ajar yang dikembangkan.

\subsubsection{Standar Kompetensi Lulusan (SKL)}

Bagian ini menentukan KI dan KD sesuai materi pokok yang dipelajari. Berdasarkan hasil identifikasi KD, maka langkah selanjutnya diuraikan indikator pencapaian dan tujuan pembelajaran yang akan dicapai peserta didik.

\subsubsection{Tugas dan Langkah Kerja}

Tahap ini terdapat pada bagian pemahaman materi yang berisi kegiatan belajar peserta didik pada pembelajaran laju reaksi. Kegiatan ini disusun berdasarkan sintaks model PBL yaitu: orientasi peserta didik dengan masalah, mengorganisasi peserta didik dalam grup, penyelidikan, mengembangkan dan menyajikan karya, serta analisis dan evaluasi masalah ${ }^{[12]}$. Secara umum, LKPD berbasis PBL dapat dilihat pada Gambar 1.

\subsection{Tahap Develop}

Tahap develop dilakukan setelah tahap design dengan memberi uji validitas terhadap LKPD yang dilakukan oleh validator ahli. Setiap pengujian dilakukan perbaikan sesuai arahan validator. Tahap uji validitas LKPD yang dibuat, divalidasi oleh 5 orang validator yaitu 2 orang dosen Jurusan Kimia FMIPA UNP dan 3 orang guru kimia SMAN 1 Koto XI Tarusan. Setiap uji dilaksanakan tahapan revisi berdasarkan saran dari validator. 
Tabel 2. Komponen Isi LKPD Validator.

\begin{tabular}{|c|c|c|c|}
\hline No & Aspek yang dinilai & $\boldsymbol{k}$ & Kategori Kevalidan \\
\hline 1 & Isi LKPD sesuai dengan Kompetensi dasar 3.6 & 0,94 & Sangat tinggi \\
\hline 2 & Isi LKPD sesuai dengan Kompetensi dasar 3.7 & 1,00 & Sangat tinggi \\
\hline 3 & Isi LKPD sesuai dengan Kompetensi Dasar 4.6 & 0,88 & Sangat tinggi \\
\hline 4 & Isi LKPD sesuai dengan Kompetensi Dasar 4.7 & 1,00 & Sangat tinggi \\
\hline 5 & Lembar kerja sesuai dengan IPK 3.6.1 & 0,82 & Sangat tinggi \\
\hline 6 & Lembar kerja sesuai dengan IPK 3.6.2 & 0,88 & Sangat tinggi \\
\hline 7 & Lembar kerja sesuai dengan IPK 3.7.1 & 0,88 & Sangat tinggi \\
\hline 8 & Lembar kerja sesuai dengan IPK 4.6.1 & 0,88 & Sangat tinggi \\
\hline 9 & Lembar kerja sesuai dengan IPK 4.6.2 & 0,82 & Sangat tinggi \\
\hline 10 & Lembar kerja sesuai dengan IPK 4.7.1 & 0,82 & Sangat tinggi \\
\hline 11 & Lembar kerja sesuai dengan IPK 4.7.2 & 0,88 & Sangat tinggi \\
\hline 12 & Lembar kerja sesuai dengan IPK 4.7.3 & 0,88 & Sangat tinggi \\
\hline 13 & Lembar kerja sesuai dengan IPK 4.7.4 & 0,82 & Sangat tinggi \\
\hline 14 & Model pembelajaran yang digunakan sesuai dengan materi & 0,75 & Tinggi \\
\hline 15 & $\begin{array}{l}\text { Isi LKPD dapat menambah wawasan pengetahuan peserta didik } \\
\text { SMA/MA }\end{array}$ & 0,82 & Sangat tinggi \\
\hline \multicolumn{2}{|r|}{$k$ dari aspek komponen isi } & 0,87 & Sangat tinggi \\
\hline
\end{tabular}

$\boldsymbol{k}=$ Formula Kappa Cohen

\subsubsection{Uji Validasi}

Uji validitas dilakukan dengan penggunaan instrumen validasi, Instrumen validasi digunakan untuk melihat kesesuaian bahan ajar yang dikembangkan dengan kriteria atau perlu adanya revisi ${ }^{[13]}$.Uji ini dinilai berdasarkan empat komponen.

\section{Komponen Kebahasaan}

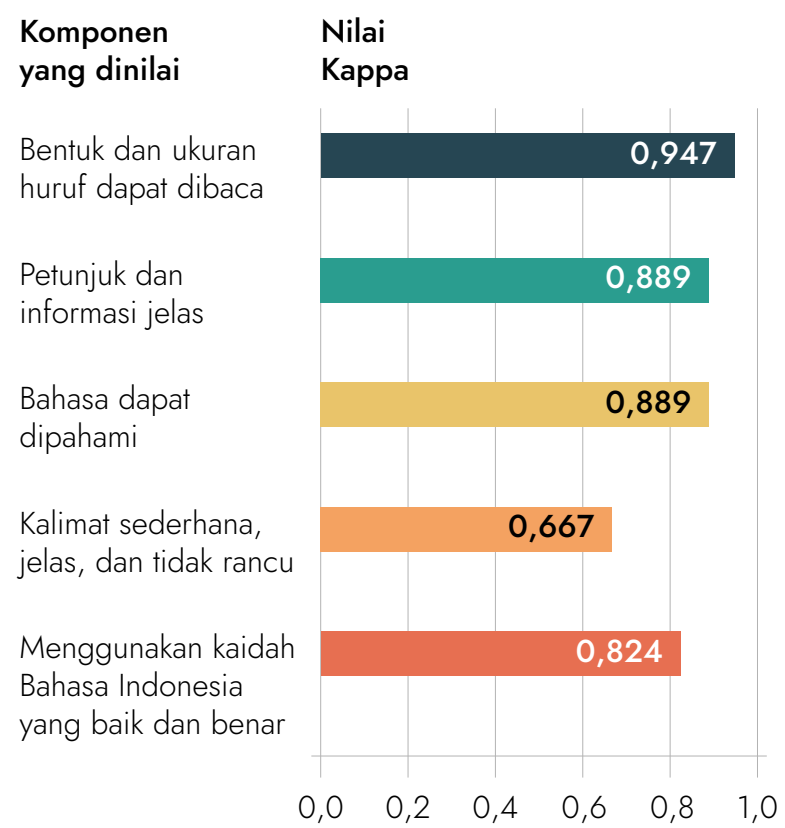

Gambar 2. Komponen Kebahasaan.
Setiap komponen disesuaikan dengan ketentuan yang ada, diantaranya: kelayakan isi, kebahasaan, dan penyajian serta kegrafikan.

\subsubsection{Komponen Kelayakan Isi}

Produk yang telah dinilai validator berkaitan dengan adanya kesesuaian KD dengan produk, kesesuaian isi dengan materi,dan kebenaran substansi materi pembelajaran, serta manfaat sebagai penambah wawasan yang terdapat pada komponen kelayakan isi. Hasil penilaian validator yang sudah dianalisis, dapat terlihat pada Tabel 2.

Berdasarkan analisis data yang dituangkan dalam Tabel 2, secara keseluruhan LKPD berbasis PBL yang dikembangkan, memiliki kategori sangat tinggi. Hal ini diketahui melalui analisis uji validitas yang telah dilakukan oleh lima validator ahli dengan rata-rata kappa 0,87. Penilaian di atas mencakup kesesuaian isi LKPD yang dikembangkan dengan materi laju reaksi. Dari nilai rata-rata kappa tersebut diketahui LKPD yang dikembangkan telah sesuai dengan tuntutan kurikulum 2013 revisi 2018. Komponen kelayakan isi meliputi: kesesuaian KD, kesesuaian dengan materi, kebenaran substansi materi pembelajaran, dan manfaat untuk penambah wawasan. Hal ini menunjukkan bahwa dalam LKPD berisi petunjuk, informasi dan bahasa yang sangat jelas serta mudah dimengerti. 
Kesesuaian isi dari komponen kelayakan dilihat dari pertanyaan, model dan soal latihan yang memiliki kesesuaian dengan model PBL. Hal ini menunjukkan tahap pengorganisasian peserta didik terhadap masalah pada LKPD dirancang dengan baik, dengan artian pemilihan masalah yang tepat sesuai konteks materi yang dipelajari. Masalah ini yang akan diselesaikan dengan cara menggali informasi dari berbagai sumber dan melakukan analisis sehingga diperoleh penyelesaiannya ${ }^{[14]}$. Selain itu, isi LKPD juga sesuai dengan tujuan pembelajaran yang diharapkan tercapai. Teori Reigeluth \& Merrill menerangkan bahwa keberhasilan pengembangan perangkat pembelajaran dapat dilihat berdasarkan pencapaian tujuan pembelajaran yang dirancang ${ }^{[15]}$.

Berdasarkanuraiandiatas, untukmeningkatkan kualitas dari suatu produk memerlukan saran dari validator. Pada komponen ini, terdapat beberapa saran dari validator, diantaranya perbaikan sintaks kedua dengan mengaitkan pembelajaran laju reaksi dengan model yang digunakan, menambahkan

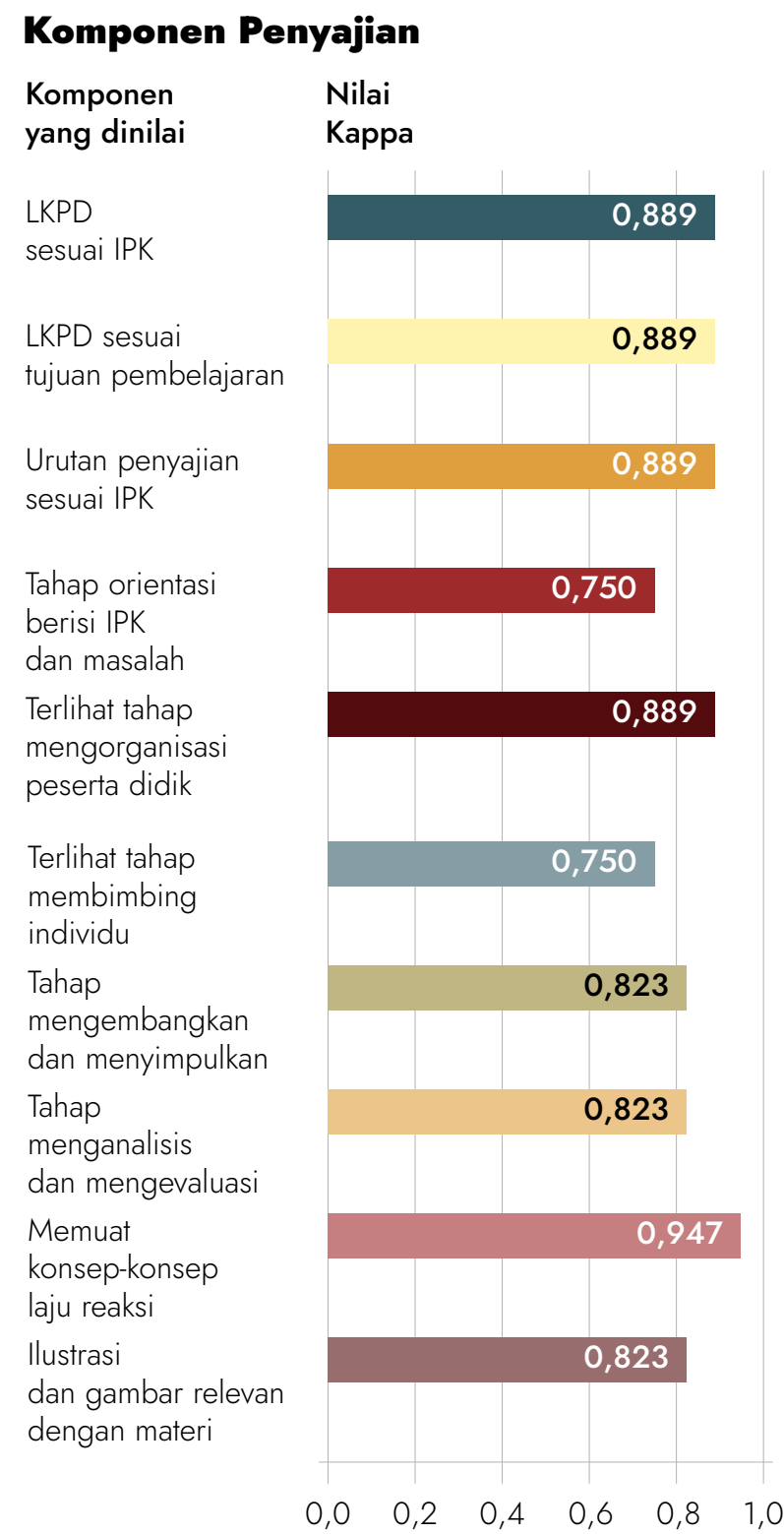

Gambar 3. Komponen Penyajian. masalah yang berkaitan dengan materi laju reaksi dan menambahkan data-data pada sintaks yang terdapat pada model yang digunakan.

\subsubsection{Komponen Kebahasaan}

Hasil penilaian validator menyangkut komponen kebahasaan dari produk yang dikembangkan dapat dilihat dari Gambar 2 . Berdasarkan Gambar 2, terlihat bahwa petunjuk informasi yang digunakan dan penggunaan kalimat yang sederhana serta tidak rancu didapat validitas paling rendah sebesar 0,66 . Hal ini dikarenakan pada LKPD yang dikembangkan masih terdapat beberapa kesalahan penggunaan kalimat sehingga perlu perbaikan agar tidak rancu dalam memahaminya. Sedangkan keterbacaan huruf dan banyaknya informasi memiliki tingkat validitas yang tinggi sebesar 0,88. Untuk penggunaan kaidah bahasa yang baik dan benar diperoleh validitas sebesar 0,82 . Secara keseluruhan validitas untuk komponen kebahasaan memiliki nilai validitas 0,84 dengan kategori sangat tinggi untuk diuji cobakan.

\subsubsection{Komponen Penyajian}

Hasil analisis data penilaian komponen penyajian oleh validator dapat dilihat pada Gambar 3. Gambar 3 menunjukkan bahwa pada konsep-konsep materi laju reaksi memiliki validitas paling tinggi sebesar 0,94. Sedangkan validitas terendah terletak pada penyajian model sintaks pertama dan sintaks ketiga pada materi laju reaksi memiliki validitas sebesar 0,75 . Hal ini dikarenakan kurang banyaknya data berupa gambar yang mendukung sintaks pertama dan soal-soal yang terdapat pada sintaks ketiga masih perlu diperbaiki. Penilaian terhadap komponen penyajian secara keseluruhan diperoleh rata-rata kappa senilai 0,84, kategori validitas sangat tinggi. Hal ini berarti bahwa

\section{Komponen Kegrafikan}

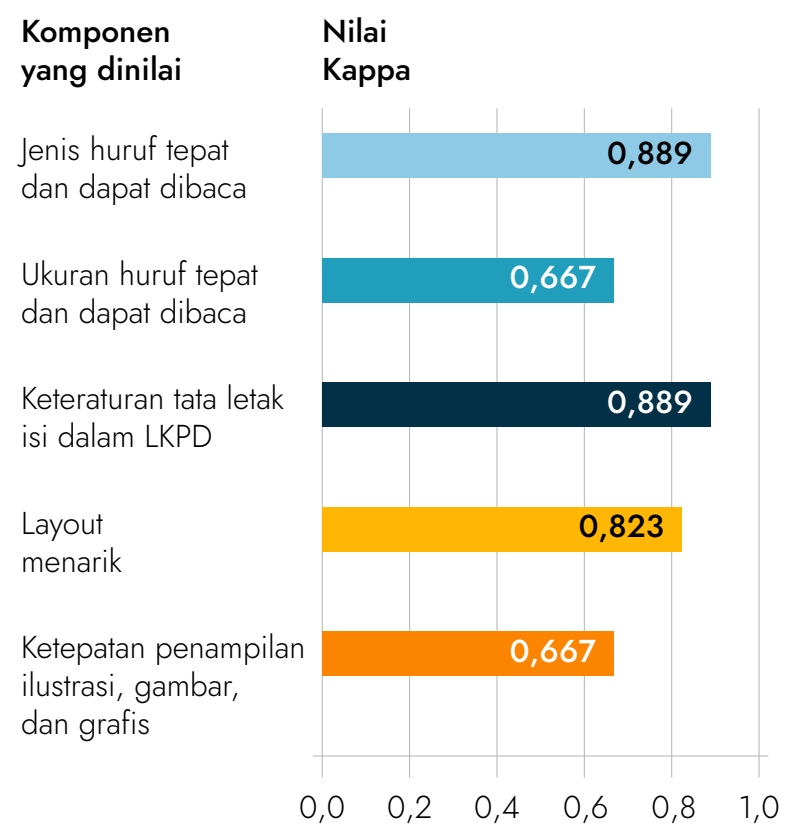

Gambar 4. Komponen Kegrafikan. 


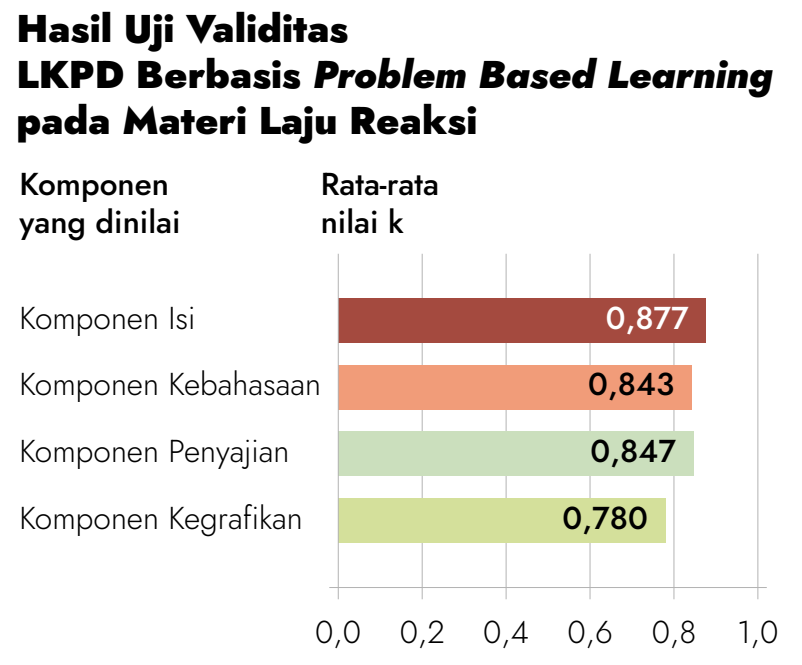

Gambar 5. Analisis Validasi LKPD materi Laju Reaksi.

LKPD yang dikembangkan telah sesuai dengan IPK ataupun urutan penyajian materinya berdasarkan model PBL.

\subsubsection{Komponen Kegrafikan.}

Hasil analisis data komponen kegrafikan oleh validator dapat dilihat pada Gambar 4. Hasil pengolahan data penilaian komponen kegrafikan LKPD oleh validator dapat dilihat pada Gambar 4, validitas terendah pada layout, tampilan cover dan penerapan ilustrasigambardangrafisyaitu 0,66. Halini dikarenakan adanya gambar yang kurang sesuai ditampilkan pada cover maupun isi LKPD. Sedangkan yang memiliki nilai validitas tertinggi terdapat pada ketepatan penggunaan huruf. Penilaian komponen kegrafikan memiliki rata rata kappa 0,78 dan kategori kevalidan tinggi. Aspek penilaian kegrafikan ini meliputi: penggunaan font, layout, ilustrasi, dan desain tampilan.

Suatu produk dikatakan valid apabila telah disesuaikan dengan kurikulum yang ada dan berhubungan antara satu dengan yang lainnya. Berdasarkan hal ini, dapat diketahui bahwa LKPD yang dikembangkan telah sesuai dengan aspek penilaian yang ada. Hasil penilaian dari masing-masing komponen dapat dilihat dalam Tabel 3 dan Gambar 5.

Berdasarkan Gambar 5, diperoleh hasil analisis validitas berdasarkan komponen berturut-turut yaitu 0,$87 ; 0,84 ; 0,84 ;$ dan 0,78 sehingga diperoleh rata-rata validitas LKPD sebesar 0,83 . Hal ini dapat diketahui bahwa LKPD yang dikembangkan telah valid dengan kategori kevalidan sangat tinggi untuk diuji cobakan. Selanjutnya, dilakukan perbaikan agar diperoleh LKPD yang lebih baik disesuaikan dengan saran dari penguji dan validator.

\section{SIMPULAN}

Berdasarkan penelitian yang telah dilakukan, didapatkan dua kesimpulan bahwa telah dihasilkan LKPD berbasis PBL pada materi laju reaksi yang dapat membantu peserta didik dalam menemukan konsep sendiri dan LKPD terhasil diketahui ratarata validitas sebesar 0,83 artinya memiliki kategori kevalidan sangat tinggi.
Tabel 3. Hasil analisis validitas LKPD yang dilakukan oleh validator

\begin{tabular}{c|c|c|c} 
No & $\begin{array}{c}\text { Komponen } \\
\text { penilaian }\end{array}$ & $\mathbf{K}$ & Kategori \\
\hline 1 & Kelayakan Isi & 0,87 & $\begin{array}{c}\text { Sangat } \\
\text { tinggi }\end{array}$ \\
\hline 2 & Kebahasaan & 0,84 & $\begin{array}{c}\text { Sangat } \\
\text { tinggi }\end{array}$ \\
\hline 3 & Penyajian & 0,84 & $\begin{array}{c}\text { Sangat } \\
\text { tinggi }\end{array}$ \\
\hline 4 & Kegrafikan & 0,78 & Tinggi \\
\hline $\mathbf{k}$ dari aspek komponen isi & $\mathbf{0 , 8 3}$ & $\begin{array}{c}\text { Sangat } \\
\text { tinggi }\end{array}$ \\
\hline
\end{tabular}

$$
k \text { = formula kappa Cohen }
$$

\section{REFERENSI}

1. Kementerian Pendidikan dan Kebudayaan Republik Indonesia. Dokumen Kurikulum 2013. Jakarta: Departemen Pendidikan dan Budaya; 2012.

2. Hosnan M. Pendekatan Saintific dan Kontektual dalam pembelajaran Abad 21. Bogor: Ghalia Indonesia; 2014.

3. Putri SD, Djamas D. Pengembangan Perangkat Pembelajaran Fisika Berpikir Keterampilan Berpikir Kritis dalam Problem-Based Learning. Jurnal Ilmiah Pendidikan Fisika Al-Biruni; 2017

4. Gunantara G, Suarjana MI, Riastini PN. Penerapan Model Pembelajaran Problem Based Learning untuk Meningkatkan Kemampuan Pemecahan Masalah Matematika Siswa Kelas V. Jurnal Mimbar PGSD Universitas Pendidikan Ganesha. 2014;2(1).

5. Rahayu R, Laksono WE. Pengembangan Perangkat Pembelajaran IPA Berbasis Problem-Based Learning. Jurnal Kependidikan. 2015;45(1):29-43.

6. Fitriani, Hasan M, Musri. Pengembangan Lembar Kerja Peserta didik (LKPD) Berbasis Masalah untuk Meningkatkan Pemahaman Konsep dan Aktivitas Belajar Peserta Didik pada Materi Larutan Penyangga. Jurnal Pendidikan Sains Indonesia. 2016;04(01):26-42.

7. Jasperina, Suryelita. Pengembangan LKPD Berbasis Problem Based Learning pada Materi Alkanal dan Alkanon untuk kelas XII SMA/ MA. Edukimia Jurnal. 2019;1(03):112-117.

8. Astuti S, Danial M, Anwar M. Pengembangan LKPD Berbasis PBL (Problem Based Learning) Untuk Meningkatkan Keterampilan Berpikir Kritis Peserta Didik Pada Materi Kesetimbangan Kimia. Chemistry Education Review. 2018;1(2).

9. Rhaska G, Mawardi M. Lembar Kerja Peserta Didik Materi Laju Reaksi Berbasis Problem Based Learning Untuk Kelas XI SMA/MA. Entalpi Pendidikan Kimia. 2020;1(1). 
10. Trianto. Mendesain Model Pembelajaran Inovatif-Progresif: Konsep, Landasan, dan Implementasinya pada Kurikulum Tingkat Satuan Pendidikan (KTSP). Jakarta: Kencana Prenada Media Group; 2012.

11. Boslaugh S, Watters PA. Statistics in a Nutshell, A Desktop Quick Reference. O'Reilly Media; 2008.

12. Sani RA. Pembelajaran Saintifik untuk Implementasi Kurikulum. Jakarta: PT. Bumi Aksara; 2014.

13. Sugiyono. Metode Penelitian Kuantitatif dan Kualitatif dan R\&D. Bandung: Alfabeta; 2010,

14. Aji S, Huda MN, Rismawati A. Pengembangan Modul Pembelajaran Fisika Berbasis Problem Based Learning untuk Meningkatkan Kemampuan Pemecahan Masalah Fisika. Science Education Journal. 2017;1(1):36-51.

15. Degeng INS. Ilmu Pembelajaran: Klasifikasi Variabel untuk Pengembangan Teori dan Penelitian. Bandung: Arasmedia; 2013. 